\title{
Overweight and Obesity among Children under 18 year attended Nutritional Clinic in AL-Diwaniyah Governorate, Iraq, 2016
}

Fatima Abd Alkathem Redha Alkhalidi

College of Nursing / AL-Qadisiyah University/ Iraq.

\begin{abstract}
Globally, Childhood malnutrition is growing problem and an increasing public health concern in developed and developing countries. significantly the obesity in children are have impact on health physical and psychological aspect. Obesity in adulthood lead to causes chronic diseases like diabetes and cardiovascular diseases at adult age. This study aimed to estimated the overweight and obesity rate among children.
\end{abstract}

A descriptive cross sectional study was conduct in AL-dewania teaching hospital, ALdewania city, Iraq during 2016. the study sample of under 18 years children was selected randomly from children who attended the nutritional clinic. By using SPSS soft ware(SPSS version 18. 0) analysis of data was carried out, version 20.0(SPSS-20.0). Statistical significance will be considered when the P-value was equal or less than 0.05 .

A total study sample was 335 children, 97(29\%) was male while 238( 71\%) was female. mean \pm SD of age ,weight, height and BMI was $(10.7 \pm 4.5),(46.9 \pm 29.9)$, $(136.5 \pm 24.9)$ and $(22.6 \pm 9.2)$ respectively. overweight and obesity was $41.2 \%$ most of them female ( $79 \%$ ) while underweight was $22.6 \%, 61.8 \%$ was female with statistical significant ( $\mathrm{P}$ value 0.0001 ). The age group 5-10 year was represented $37.6 \%$, then age group 11-15year was $32.5 \%$ with significant association. we concluded that the overweight and obesity rate was high among children under 18 year, female and age group 11-15 year had have higher rate.

Keyword: Overweight and obesity, children under 18 year, AL-dewania, Iraq.

\section{Introduction}

Obesity was defined as a abnormal or excessive fat accumulation in adipose tissue, which impaired the health. In childhood there is no agreement on a limited point for excess fatness of overweight or obesity.[1] The Center for Disease Control and Prevention considered that the obesity was at or above the $95^{\text {th }}$ percentile of body mass index(BMI) for age while "at risk for overweight" when between $85^{\text {th }}$ and $95^{\text {th }}$ percentile of BMI for age.[2,3] Obesity can be measured by different methods like body mass index (BMI), waist circumference, waist-hip ratio, skin fold, and percent body fat measurements. the most common used method is BMI in the EMRO countries, also the waist circumference some time used to measure obesity (4). obesity and overweight considered as one of 


\section{Email:utjmed@utq.edu.iq}

the most serious public health problem and challenges of world wild. obesity considered as global problem that and affecting many of countries (low and middle income) specially in urban settings. The number of overweight children is estimated to be increasing with time to reach more than 42 million child in near future most of them are living in developing countries.(4)

The prevalence of children obesity have been noted in developed and developing countries but its prevalence is more increasing in developing countries.(5). Girls children are likely to be obese more than boy due to inherent hormonal differences.[6]

There are many causes of children obesity, the most important one is genetics that may be BMI reach 25 to $40 \%$ heritable.[7] the genetic susceptibility accounts for less than $5 \%$ and usually needs to be coupled with environmental and behavioral factors to affect weight gain or loss.[7,8]

Other possible causes for obesity are basal metabolic rate and differences in basal metabolic rates are not likely to be responsible for the increasing rates of overweight and obesity.[7]

Other possible causes are the mealtime, meal structure, families who eat together consume more healthy foods, eating out, watching TV while eating all these causes are associated with a highe intake of fat.[9]

also some studies indicates that taste, hunger and price, is considered important factor in adolescents snack choices.[10]

In last recent years Increased fast food consumption has been linked with obesity among many families, especially those with two parents working outside the home, which are favorite this food by their children because it convenient and inexpensive.[11]

In Al-Dewaniyah city there are still lacking the real data about the overweight and obesity prevalence specially among children due to deficiency of studies about this important subject.

The study objective is to estimate the overweight and obesity rate among children under 18 in nutrition clinic of province of Al-Dewaniyah.

\section{Method}

A descriptive cross sectional study with analyzed element. the study was conducted in aldewania city-south of Iraq during 2016. A total of study sample of under 18year children was selected randomly from people who attended to the nutritional clinic as patient or for council visit. the study include all children under 18 year and exclude all children with acute or chronic disease associate or related to nutrition. multiple variable will be considered like age, gender, weight, height and BMI.

data analysis was carried out by using SPSS soft ware (SPSS version 18. 0) Statistical significance will be considered when the P-value was equal or less than 0.05 Data will be present in form of tables of numbers and percentage. The suitable statistical test was used for testing the significance of association between variable under study. 


\section{Result:}

A total study sample was 335 children which selected randomly from 1400 person who attended nutrition clinic as a patient or for counseling(figure 1). Male was 97 (29\%) while female was $238(71 \%)$.

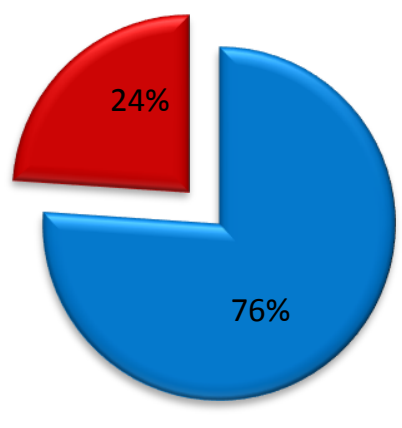

$\square$ adult

घhildren

Fig.1 Study Sample

Table 1: Distribution of Mean \pm SD of Age ,Weight, Height and BMI.

The total mean \pm SD of age ,weight, height and BMI was $(10.7 \pm 4.5),(46.9 \pm 29.9)$, $(136.5 \pm 24.9)$ and $(22.6 \pm 9.2)$ respectively.

Female mean \pm SD of age, weight height and BMI was $11.2 \pm 4.43,50.5 \pm 30.0,139.1$ \pm 23.6 and $23.8 \pm 9.6$ respectively, while for male it was $9.2 \pm 4.4,37.8 \pm 28.0,129.7 \pm$ 27.9 and $19.5 \pm 7.5$ respectively, with statistical significant ( $p$ value $<0.001$ ). As shown in table 1.

\begin{tabular}{|l|c|c|c|c|}
\hline \multicolumn{1}{|c|}{ variable } & Male (n=97) & Female (n=238) & \multicolumn{2}{|c|}{ Total (n=335) } \\
\cline { 2 - 5 } & Mean \pm SD & Mean \pm SD & Mean \pm SD & $\begin{array}{c}\text { P- } \\
\text { value }\end{array}$ \\
\hline Age (years) & $9.2 \pm 4.4$ & $11.2 \pm 4.43$ & $10.6 \pm 4.5$ & $<0.001$ \\
\hline $\begin{array}{l}\text { Weight } \\
\text { (Kg) }\end{array}$ & $37.8 \pm 28.0$ & $50.5 \pm 30.0$ & $46.8 \pm 29.9$ & $<0.001$ \\
\hline Height $(\mathbf{c m})$ & $129.7 \pm 27.9$ & $139.1 \pm 23.6$ & $136.4 \pm 25.3$ & 0.001 \\
\hline $\begin{array}{l}\text { BMI } \\
(\text { Kg/m2) }\end{array}$ & $19.5 \pm 7.5$ & $23.8 \pm 9.6$ & $22.6 \pm 9.2$ & $<0.001$ \\
\hline
\end{tabular}




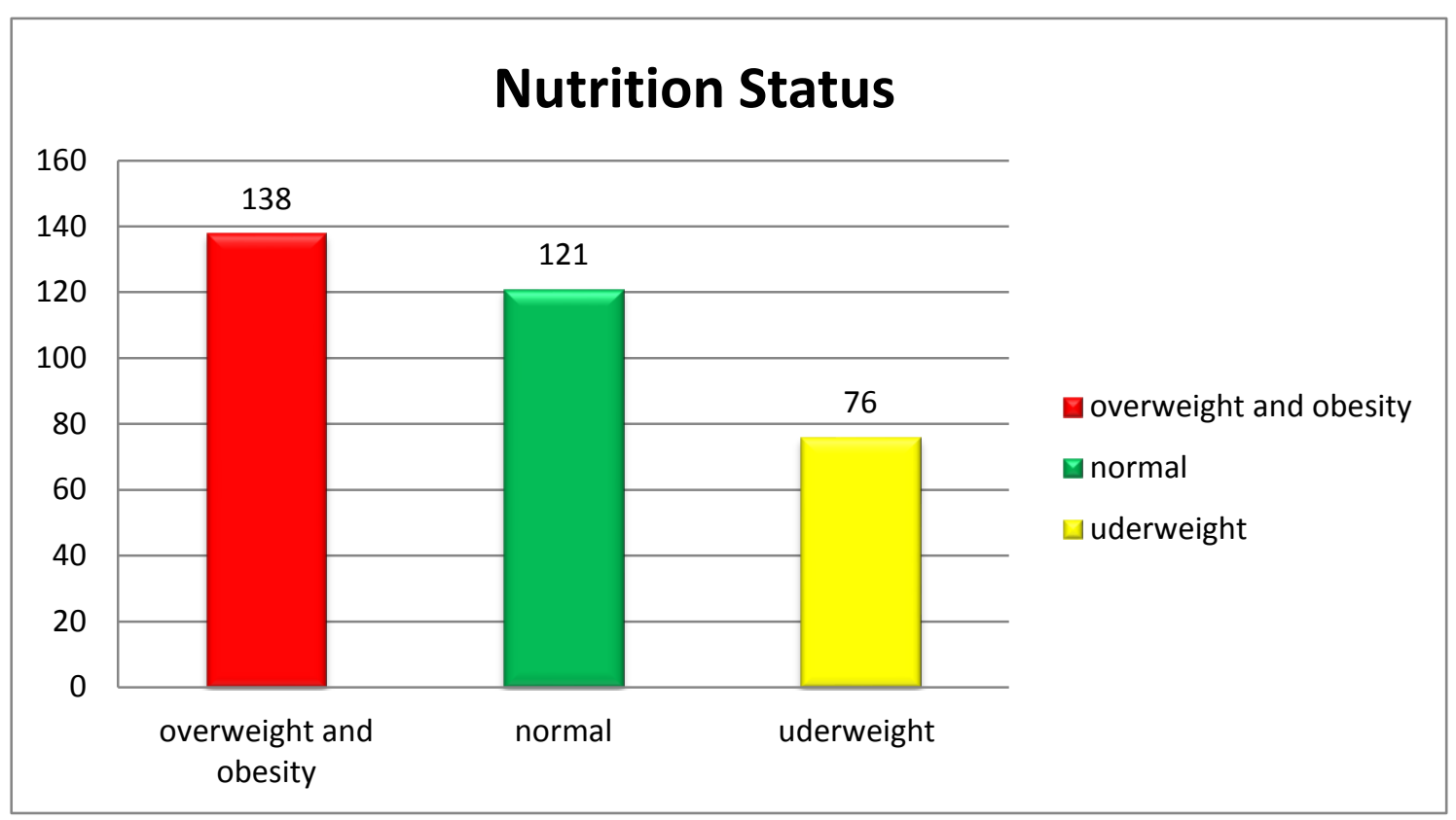

Figure 2: Nutrition status distribution. Our study was found that overweight and obesity rate was $41.2 \%$ (138) while underweight was $22.6 \%$ (76) and normal was $36.2 \%(121)$. As shown in figure 2.

Table 2:distribution of nutritional status according to the gender. Regarding gender; the study was found that overweight and obesity rate and underweight rate in female was higher than that in male ( $79 \%, 61.8 \%$ vs. $21 \%, 38.2$ respectively) as shown in table 2 .

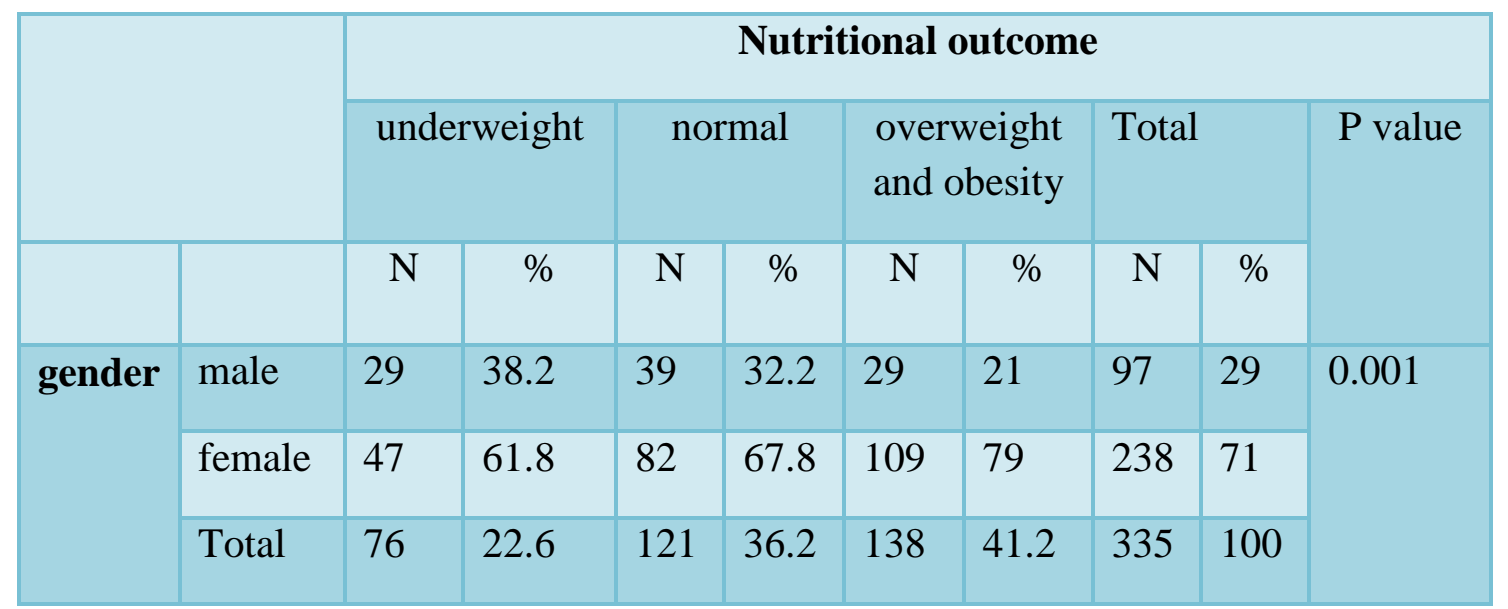


Table 3:distribution of nutritional status according to the age group. Age group 5-10 year was represented $37.6 \%$ followed by age group $11-15$ year was $32.5 \%$. while the rate of overweight and obesity was higher(42.8\%) among age group 11-15 year than other age group, with significant association(P value 0.001 ) as shown in table 3.

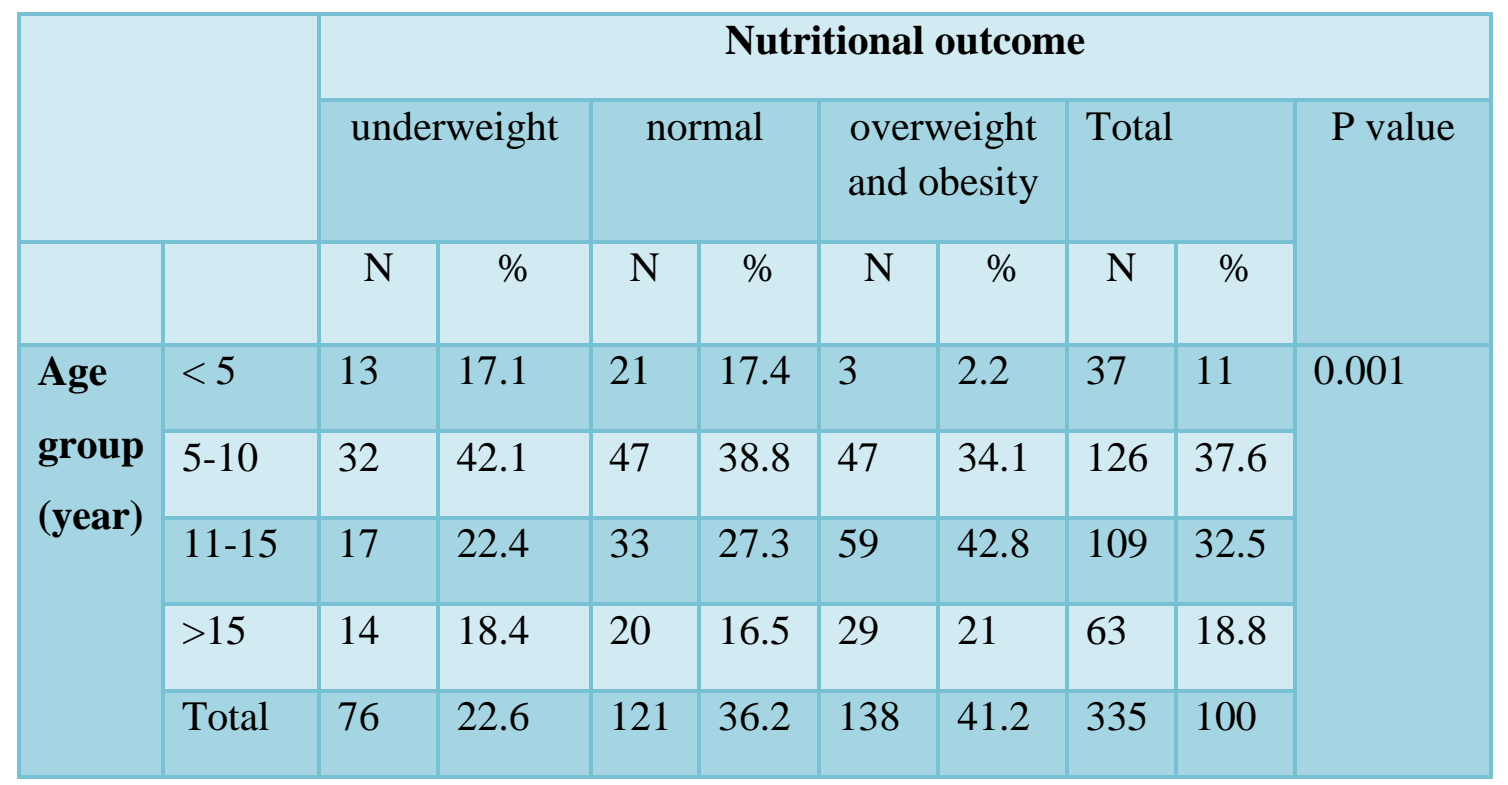

\section{Discussion}

obesity and overweight considered as one of the most serious public health problem and challenges of world wild. The prevalence of children obesity have been noted in developed and developing countries but its prevalence is more increasing in developing countries.(5)

Our study revealed that tow-third of sample were female children and onethird were male and the mean \pm SD of age, weight, height and BMI was higher in female children than male children with statistical significant ( $\mathrm{p}$ value < $0.001)$. this result in agreement with other studies that conducted in eight European countries (12) but it was disagree with other study that carry out in $\operatorname{Iraq}(13)$ this may explain by most of attended clients to nutrition clinic were females. The present study found that overweight and obesity rate of children was high $(41.2 \%)$ from which more than $3 / 4$ of them was female, while underweight was $22.6 \%$ also more than $61 \%$ of them was female children. with significant association to gender.(P value 0.001$)$ This result may be due to the community limitations and rules that prevent female from walking and exercise in public places and gardens, also the absence of creative places specific for girls in comparison to boys. this result was similar to other study $(12,14,15,16,17)$ and disagree with other study that done in Iraq (18) 


\section{Email:utjmed@utq.edu.iq}

Regarding age: although $37.6 \%$ of children in age group of 5-10 year old the overweight and obesity was higher (42.8\%) among age group 11-15 year than other age group with significant association( $\mathrm{P}$ value 0.001$)$. which is consistent with the findings of previous studies, in Iraq and other countries(18,19)and it may be explain that most of children in this age were preferred to eat fast food and interesting to play a computerized games and watch TV especially at late time of night.(9)

\section{Conclusion}

The obesity and overweight rate was high among children age and more common in age group 11-15 years.

Obese female was more than male.

\section{Recommendations}

1. increase the awareness and health education about obesity and its complication among children and how to prevent the risk factor for body weight gain.

2. Encourage the school sport class and physical activities for children.

3. Educate families for walking and playing in public or private gardens

4. Checking the height and weight regularly to be in safe side.

\section{References}

1. World Health Organization. (2006): Obesity and overweight. Fact sheep $\mathrm{n}^{\circ}$ 311;2006.

2. WHO, Obesity An epidemic, 2000 Available from: http://www.who.int/nutrition/topics/obe sity/en/. [Accessed Apr. 11, 2009]

3. Bleich S, Cutler D, Murray C, Adams A . Working paper 12954: Why is the developed world obese? National Bureau of Economic Research, 2007. Available from: http://www.nber.org/papers/w12954. [Accessed on Aug. 21, 2008]

4. Haslam DW, James WPT. Obesity Seminar. The Lancet, 2005; 366: 1197209.

5. Ghosh A. Explaining overweight and obesity in children and adolescents of Asian Indian origin: The Calcutta childhood obesity study. Indian J Public Health. 2014;58:125-8. [PubMed]

6. Gupta RK. Nutrition and the Diseases of Lifestyle. In: Bhalwar RJ, editor. Text Book of Public health and Community Medicine. 1st ed. Pune: Department of community medicine AFMC, New Delhi: Pune in Collaboration with WHO India Office; 2009. p. 1199.

7. Anderson PM, Butcher KE. Childhood obesity: Trends and potential causes. Future Child. 2006;16:19-45. [PubMed]

8. Center for Disease Control and Prevention. Contributing factors. 2010. [Last accessed on 2014 Jul 01]. Available from: http://www.cdc.gov//obesity/childhood/ contributing_factors.html

9. McGavock JM, Torrance BD, McGuire KA, Wozny PD, Lewanczuk RZ. Cardiorespiratory fitness and the risk of overweight in youth: the Healthy 


\section{Email:utjmed@utq.edu.iq}

Hearts Longitudinal Study of Cardiometabolic Health. Obesity (Silver Spring). 2009 Sep. 17(9):1802-7.

10. Story M, Neumark-stainzer D, French S. Individual and environmental influences on adolescent eating behaviours. J Am Diet Assoc. 2002;102:S40-51. [PubMed]

11. Niehoff V. Childhood obesity: A call to action. Bariatric Nursing and Surgical Patient. Care. 2009;4:17-23.

12. W Ahrens, I Pigeot, H Pohlabeln, S De Henauw, Lissner, D Molnár, LA Moreno, M Tornaritis, $\mathrm{T}$ Veidebaum and A Siani on behalf of the IDEFICS consortium. Prevalence of overweight and obesity in European children below the age of 10. International Journal of Obesity (2014) 38, S99-S107

13. Lafta RK1, Kadhim MJ. Childhood obesity in Iraq: prevalence and possible risk factors. Ann Saudi Med. 2006.

14. 2 Manios Y, Costarelli V. Childhood obesity in the WHO European Region. In: Moreno LA, Pigeot I, Ahrens W (eds). Epidemiology of Obesity in Children and Adolescents-Prevalence and Etiology, vol. 2. Springer Series on Epidemiology and Public Health. Springer: New York, NY, USA, 2011, pp 43-68.
Web Site: https://imed.utq.edu.iq

15. Pigeot I, Barba G, Chadjigeorgiou C, de Henauw S, Kourides Y, Lissner L et al. Prevalence and determinants of childhood overweight and obesity in European countries: pooled analysis of the existing surveys within the IDEFICS Consortium. Int J Obes (Lond) 2009; 33: 1103-1110.

16. Wijnhoven TM, van Raaij JM, Spinelli A, Rito AI, Hovengen R, Kunesova $\mathrm{M}$ et al. WHO European Childhood Obesity Surveillance Initiative 2008: weight, height and body mass index in 6-9-year-old children. Pediatr Obes 2013; 8: 79-97.

17. Steven M Schwarz, Jatinder Bhatia. Obesity in Children. Updated: Mar 29, 2016.

18. Sherzad Abdulahad Shabu, Namir Ghanim Al-Tawil. Prevalence of Childhood Obesity Among a Sample of Basic Education School Children in Erbil City. middle east journal of family medicine, volume 10. issue 10. 2012.

19. Krassas GE1, Tzotzas T, Tsametis C, Konstantinidis T. Prevalence and trends in overweight and obesity among children and adolescents in Thessaloniki, Greece. J Pediatr Endocrinol Metab. 2001;14 Suppl 5:1319-26; discussion 1365. 


\section{زيادة الوزن والسمنة بين الاطفال تحت عمر 1/ سنة المراجعين لعيادة

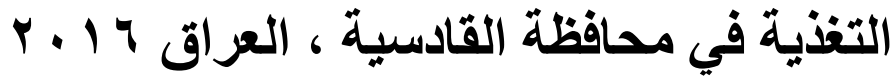

فاطمة عبد الكاظم رضا الخالدي

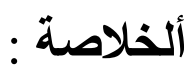

در اسة عرضية اجريت على هبr طفل تحت عمر \1 سنة، تم اختيار هم عشو ائيا من بين المر اجعين لعيادة التغذية في مستشفى الديوانية التعليمي في محافظة القادسية

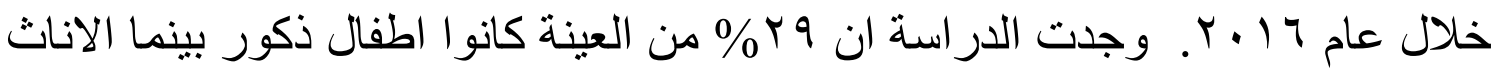

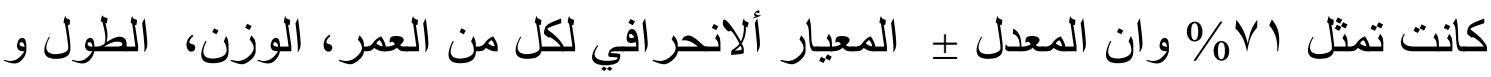
مؤشر كتلة الجسم كانت (Y, (•)

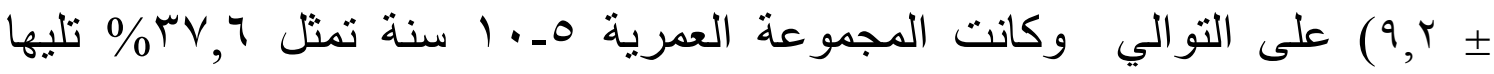
المجموعة العمرية 11 ـ1 سنة. كما بينت الدراسة ان نسبة زيادة الوزن و السمنة

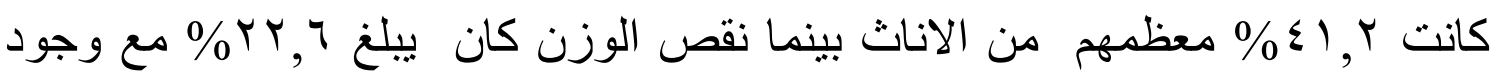
استدلال احصائي لتلك العلاقة. تستتج الدراسة بان معدل زيادة الوزن و السمنة كان عاليا بين الاطفال تحت عمر 1/ سنة خاصة عند الاناث وفي المجاميع العمرية || ( ) 20 